\title{
BREAKFAST BOX: AN EFFORT TO DEVELOP VOCABULARY MASTERY
}

\author{
Dewi Lestari \\ SMP Muhammadiyah 2 Surakarta
}

dhewitta@yahoo.com

\begin{abstract}
Vocabulary is difficult skill for students on SMP Muhammadiyah 2 Surakarta. The students usually tend to listen, speak, read, and write text based on their vocabulary mastering. Once they get difficulty in understanding text, they will lose their courage to do more instructions. In order to build or understand a simple sentence, they need to open dictionary per word. As a result, students will easily lose interest and motivation to learn more. This research is carried out in SMP Muhammadiyah 2 Surakarta. It is on Jl. Kerinci No. 15. The research is conducted from July until Agustus 2018. The subject of this research is the IX-B grade students of SMP Muhammadiyah 2 Surakarta. The researcher chooses class B because the students have difficulties in understanding text due to the lack of vocabularies. That is why the researcher decides to improve their mastery in vocabulary through "vocabulary breakfast box". "Vocabulary Breakfast Box" is adapted from "Kotak Sarapan Pagi" which is mostly applied at elementary school learning. It is about a board which contains of several boxes. Each box has an assignment for each student. The assignment can be the same as or different from others. It depends on the students' assessment. The assignment exists in a form of a small paper. It consists of questions about words, sentences or text comprehension. Each box has students' number or name. So, students will not go wrong to take others' assignment. By using "vocabulary breakfast box", the learning process in class has become interesting and varieties. Students are excited to try new strategy with teacher and discuss its benefits and lacks after the activity. Their vocabulary mastery becomes improved and they are able to answer most questions in each skill because they have recognized the words on the text or dialogue.
\end{abstract}

Keywords: improving, vocabulary, vocabulary breakfast box

\section{INTRODUCTION}

Vocabulary is an important part in improving students' communication ability in English, both written and spoken language. It develops the ability of listening, speaking, reading, and writing skills. Vocabulary is one of the necessary parts in gaining competence of language knowledge besides language structures, idiomatic expressions, formulaic expressions, and skill development. Students who have sufficient vocabulary will be automatically easier to master the four skills in English. They are going to face difficulties in communication with insufficient vocabulary or vice versa.

Among several parts of language knowledge, vocabulary is difficult skill for students of SMP Muhammadiyah 2 Surakarta. The students usually tend to listen, speak, read, and write texts based on their vocabulary mastering. Once they get difficulty in understanding a text, they will lose their courage to do more instructions. In order to build or understand a simple sentence, they need to open dictionary per word. As a result, students will easily lose interest and motivation to learn more. The learning process becomes so slowly. They cannot answer some simple questions because they do not understand the meaning of most words. Opening dictionaries often does not help them to overcome the problem. The limited number of dictionaries also becomes a problem. Students often do not bring them at school. As a result, a teacher should provide them from library. In fact, the number of dictionaries is not enough. The students also have difficulty in using dictionary. They are not accustomed to using it. Considering the proceeding problem, a teacher needs to apply various techniques and strategies. One of them is 'breakfast box'. This learning strategy will hopefully not make dictionary dependence. It is also hoped it will increase their competence achievement.

Based on the background of the study explained before, the writer formulates the problem on how will vocabulary breakfast box improve students' vocabulary at the ninth grade of SMP Muhammadiyah 2 Surakarta.

\section{MATERIALS AND METHODS}

\subsection{RESEARCH METHOD}

This research is carried out in SMP Muhammadiyah 2 Surakarta. It is on Jl. Kerinci No. 15. The research is conducted from July until August 2018. The subject of this research is the ninth-grade students of SMP Muhammadiyah 2 Surakarta. It consists of five classes namely class A, B, C, D, and E. The researcher focuses on the IX-D. The class consists of 25 students, 12 boys and 13 girls. The researcher chooses class B because the students have difficulties in understanding text due to the lack of 
vocabularies. That is why the researcher decides to improve their mastery in vocabulary through "vocabulary breakfast box".

The research method used in this study is an action research. Arikunto (2009) defines Class Action reasearch as follows:

Research: the activity of observing object through using specific way or methods to obtain useful data or information in enhancing the quality of a certain thing that attract the researcher interest.

Action: referring to a certain activity done on purpose or on a certain reason. In the research, students activity cycles are formed.

Class: a group of students in the same certain length of time, receiving the same lesson from the same teacher.

Wallace (1999: 4) states that action research is basically a way of reflecting on a teacher's teaching (or teacher training, or management of an English Departemnt, or whatever it is the teacher does in ELT). It is done systematically by collecting data on teacher's everyday practice and analizing it in other to come to some decisions about what the teacher's future practice should be (in Siswanto).

Kemmis (1988: 17) state that there are three characteristics of action research. The action research carried out by technical. The aim is effectiveness or effiency of educational practice and professional development. The next action research is practical. The aim is practioners' understanding and transformation of their consciousness. The last is emancipatory. The aim is participants' emancipation from the dictates of tradition, self-deception, coercion, their critique of bureaucratic systematisation and alsovtransformation of organisation and of the educational system. (Zuber-Skerritt, 1996: 4)

In this study, the classroom action research that is conducted is an attempt to improve students' vocabulary mastery. This classroom action research is going to be carried out through the collaboration of the teacher. The practical action is implemented by the use of "Vocabulary Breakfast Box". The effects of the action can be known after using the media in teaching. The reflection shows whether the method can improve the students' vocabulary mastery.

\subsection{ACTION RESEARCH MODEL}

This action research uses a model developed by Kemmis (1988: 10-11). There are four steps in action research, namely plan, action, observation, and reflection. These four types are included in procedures of action research. The procedures of action research in this research are as follows:

\subsubsection{IDENTIFYING THE PROBLEM}

In this step, the researcher identifies the problem occurring in the class. The problems refer to the factors making the students difficult in reading. To identify the problem, the researcher observes the teaching learning process, interviews the teacher, and conducts a pre-test.

\subsubsection{IMPLEMENTING THE ACTION RESEARCH}

\subsubsection{Planning}

In this step, the researcher develops a plan of critically informed action to improve what was already happening. The researcher makes lesson plans about certain topic.

\subsubsection{Action}

The researcher acts to implement the plan. This is the step where the researcher conducts the technique in the class based on the plan made, the teaching learning process of uses Collaborative Language Learning technique.

\subsubsection{Observing}

The researcher observes the effects of the critically informed action in the context in which it occurs. The researcher observes how the process of the teaching learning runs. The researcher also monitors and writers the responses of the pupils in the class. In this step, the researcher is helped by the teacher. The teacher notes the events in the teaching learning process. The researcher also notes her perceptions and thought dealing with critical events or issues occurs in the classroom. He makes reflection and interpretation of the teaching in his note. 


\subsubsection{Reflection}

Reflection seeks to make sense of processes, problem and issues in strategic action. If the researcher finds some difficulties unsolved during the teaching learning process, the researcher prepares the re-planning steps. The researcher reflects on these effects as the basis for further planning, subsequent critically inform action and so on, through a succession of stages. The researcher tries to formulate the conclusion of the previous steps.

\subsubsection{TEChNigue of Collecting Data AND Data ANALYSIS}

The techniques used for collecting data are observation, interview, field notes, diaries and tests. Some information is taken by the researcher from the field notes and diaries. Then, the test is scored by looking for the mean score. After the mean score is found from the test, and it is supported by the data taken from the field note, the teacher can find how to effective media can improve student's vocabulary mastery.

The teaching learning process and the students' behavior during the action are analyzed using the observational and non-observational techniques. Based on Burns (1999: 156-160) the process of observational data analysis consists of five stages as follows:

\subsubsection{Assembling the Data}

The data assembly in this research is field notes and the researcher's diaries.

\subsubsection{Coding the Data}

Coding is process of attempting to reduce the large amount of data that are collected to more manageable categories and concepts, themes or type.

\subsubsection{Comparing the Data}

Once the data have been categorized in some way, comparisons are made to see whether themes or patterns are repeated or developed across different data gathering techniques.

\subsubsection{Building Interpretation}

This stage demands a certain amount of creative thinking as it is concerned with articulating underlying concepts and developing theories about why particular patterns of behaviors, interactions or attitudes have emerged.

\subsubsection{Reporting the Outcomes}

The final stage involves presenting an account of the research for others. A major consideration is to ensure that the report sets out the major process of the research, and the finding and outcomes are supported with examples from the data. The students' achievement data are the result of pretest and posttest in two actions. In analyzing the test score of the written test, a statistical technique is used to find the mean score of the students. The data from the written test are analyzed in order to prove whether or not teaching "Vocabulary Breakfast Box" can overcome the students' problem in vocabulary mastery.

\section{RESULTS AND DISCUSSION}

\subsection{IDEAL AND PRE-CONDITION}

\subsubsection{IDEAL CONDITION}

In English curriculum, after getting a learning process, student is expected to be able to communicate in spoken and written language. For that reason, student should master enough vocabulary. Both spoken and written skills should be mastered well in order to make the learning process easier. Let alone, students who are at the ninth grade will face a National Examination. The English exam consists of variety questions. And understanding certain information from the text is one of the goals. If the students' vocabulary is poor, their understanding on a text will be difficult as well.

The vocabulary will be used in building sentences and paragraph. In making sentences, students need to have many words. "All languages have words. Language emerges first as words, both historically and in terms of the way each of us learned our first and any subsequent languages. The coming of new words never stops, nor does the acquisition of words. Even in our first language we are continually learning new words, and learning new meaning for old words (Thornbury, 2002). 


\subsubsection{PRE-CONDITION}

In fact, students' mastery in vocabulary on IXD at SMP Muhammadiyah 2 Surakarta is far from the ideal condition. Or it is still under the minimum criterion. This fact makes the students difficult to achieve the basic competence in curriculum.

There are several things in causing students difficulties in mastering vocabulary such as vocabulary drills conducted by teacher is not appropriate to students' condition. Or the learning media is not interesting to them. The other one is students' lack of motivation. They have no habits in practicing English and they consider English as a difficult subject to learn after mathematics. Even in several other classes, some students think that English is more difficult than Mathematics.

Based on the situation, the researcher tries to overcome the problem by applying several methods or media to improve students' vocabulary mastery. One of technique and learning media used is called "vocabulary breakfast box".

\subsection{Problem ANAlysis}

A word list is the most popular way in learning vocabulary. It means teacher directly gives the words list to the students with its meaning. Students do not need to open dictionaries or discuss it with their friends. This way is considered as most practical way in teaching vocabulary because it is easy to be done. Teacher can prepare it at home. It also does not take much time in giving to the students.

This way of giving vocabulary is not always effective. Students often forget where they put it or leave it at home. Students are also depended their works on the vocabulary lists. There is other way in teaching vocabulary beside word lists. It is so called contextual. It means teacher is able to ask students to participate in the class activities. They can memorize the words at school or at home and test their knowledge at school. Here the researcher ususe those methods in learning vocabulary. The writer uses both word lists and contextual by using "vocabulary breakfast box".

\subsection{Problem Solving}

To make vocabulary learning become more meaningful and interesting for students, the researcher tries to use "vocabulary breakfast box". "Vocabulary breakfast Box" is adapted from "Kotak Sarapan Pagi" which is mostly applied at elementary school learning. It is about a board which contains of several boxes (depends on the number of students). Each box has an assignment for each student. The assignment can be the same as or different from others. It depends on the students' assessment. The assignment exists in a form of a small paper. It consists of questions about words, sentences or text comprehension. Each box has students' number or name, so students will not go wrong to take others' assignment.

Before the English class is begun, teacher hangs the board in the class and asks the students to take their assignment. Students go in front of the class in an order based on their students' number. There are several ways in making the vocabulary breakfast box. They are:

1. Make the words from the theme which is discussed in a class.

2. Mix from easy to difficult words.

3. Make it more useful by using it in every discussion of listening, speaking, reading, and writing.

4. Start the task from the easiest word lists so that students will get good scores and be motivated.

In making this media, researcher classifies the words in certain texts. Then she gives it to the students to find out the meaning in a dictionary and then memorize all those words. The words are only ten or fifteen. At the beginning of the class, teacher gives five minutes for the preparation and five minutes for doing the tasks. After finishing the job, theacher exchange the students' assignment and asks them to correct it. Those who get best score will receive small rewards for example candy, snacks, pencil, ruler, etc. what makes the students feel cheerful is not on the amount of the rewards but the proud feeling when they get the reward.

The use of this media is meant to make students memorize as many as word each week. That is why the researcher exchange the words from one student to another. The difficulty of words which are done by students can be varieted. It can be difficult words from the topic discussed in the class such as procedure texts, report text, narrative text, etc., or it can be taken from a song in listening class. 


\subsection{EXAMPLE OF TASKS}

Code: 2. Rainbow, Yudistira p. 15

\begin{tabular}{|l|l|l|l|l|l|}
\hline Gorgeous & Indah & Cloud & Awan & Prism & Prisma \\
\hline Are formed & Terbentuk & Break up & Pecah & Split & Terpecah \\
\hline Sunlight & $\begin{array}{l}\text { Cahaya } \\
\text { matahari }\end{array}$ & & & High & Tinggi \\
\hline Shinning & Bersinar & $\begin{array}{l}\text { Can be } \\
\text { seen }\end{array}$ & Dpt dilihat & Full & Lengkap \\
\hline Drops of rain & Tetesan hujan & Behind & Dibelakang & $\begin{array}{l}\text { Light } \\
\text { rain }\end{array}$ & gerimis \\
\hline Right after & Segera setelah & Low & Rendah & each & Tiap-tiap \\
\hline Shower & Hujan lebat & Strike & & & \\
\hline
\end{tabular}

After giving the vocabulary list, a teacher asks students to memorize it. It depends on the class. It can be one day before or ten minutes before the tasks. Teacher asks students to write the meaning of the words in Bahasa Indonesia.

Code: 2. Rainbow, Yudistira p. 15

\begin{tabular}{|l|l|l|l|l|l|}
\hline Gorgeous & & Cloud & & Prism & \\
\hline Are formed & & Break up & & Split & \\
\hline Sunlight & & Stream & & High & \\
\hline Shinning & & Can be seen & & Full & \\
\hline Drops of rain & & Behind & & Curve & \\
\hline Right after & & Low & & arch & \\
\hline Shower & & Strike & & & \\
\hline Light rain & & Each & & & \\
\hline
\end{tabular}

\begin{tabular}{|l|l|}
\hline Code & Text \\
\hline 1 & $\begin{array}{l}\text { The georgerous colours of a rainbow are formed by sunlight shining on drops of } \\
\text { rain. }\end{array}$ \\
\hline 2 & The best thing for rainbow is right after a shower (light rain) \\
\hline 3 & Rainbow comes when clouds break up and sunlight streams through \\
\hline 4 & Each rain drops act as a prism and split the light into a spectrum of colours. \\
\hline 5 & Rainbow can be seen only when the sun is behind you and low over the horizon \\
\hline 6 & The spectrum of colours range from red to violet. \\
\hline 7 & The lower the sun the higher the rainbow and the fuller its curved arch \\
\hline
\end{tabular}




\begin{tabular}{|l|l|}
\hline Student's Number & Tasks Code \\
\hline 1 & 7 \\
\hline 2 & 2 \\
\hline 3 & 4 \\
\hline 4 & 6 \\
\hline 5 & 1 \\
\hline Etc. & \\
\hline
\end{tabular}

Students are motivated by using the strategy. They have a variety in learning English. They are just fun and do not get bored to the situation because it takes short time. This strategy can be developed in order to discuss material in listening, speaking, reading, and writing.

\section{CONCLUSION}

The conclusion is by using "Vocabulary Breakfast Box", the learning process in class has become interesting and varieties. Students are excited to try new strategy with teacher and discuss its benefits and lacks after the activity. Their vocabulary mastery becomes improved and they are able to answer most questions in each skill because they have recognized the words on the text or dialogue.

\section{REFERENCES}

Arikunto. (2009). Penelitian Tindakan Kelas. Jakarta: PT. Bumi Aksara

Brown, Douglas. (2001). Teaching by Principles: An Interactive Approach to Language Pedagogy. NY: Longman.

Burns, Anne. (1999). Collaborative Action Research for English Language Teachers. United Kingdom: Cambridge University Press.

Cross, David. (1992). A Practical Handbook of Language Teaching. Prentice Hall Europe.

Fauziati, Endang. (2010). Teaching English As Foreign Language (TEFL). Surakarta: Era Pustaka Utama.

Halilah, Adibah. (2013). Vocabulary learning strategies among Malaysian TEVT students in GermanMalaysian Institute (GMI). Procedia-Social and Behavioral Sciences 69 (2014) 361-368.

Hopkins, David. (1993). A Teacher's Guide to Classroom Research. Buckingham: Open University Press.

Kemmis, Stephen. (1988). The Action Research Planner. Deakin University.

Kunandar. (2009). Langkah mudah Penelitian Tindakan Kelas. Jakarta. Rajawali Press.

Kurikulum Berbasis Kompetensi, Depdiknas, 2004

Parmawati, Aseptiana. Using Magic Sentences Technique to Improve Students' Vocabulary (Classroom Action Research in the first Semester Stuents of IKIP Siliwangi Bandung. IKIP Siliwangi Cimahi.

Siswanto, (2011). Improving students' reading skills through collaborative language learning. Thesis, Universitas Veteran Bangun Nusantara, Sukoharjo.

Zahedi, Yagoub (2012). The Impact of Imaginery Strategy on EFL learners' vocabulary learning. Procedia-Social and Behavioral Sciences 69 (2012) 2264-2272.

Zuber-Skerritt, (1996). New Direction in Action Researh. NY: The Falmer Press. 


\section{Author Guidelines}

The LINGUAL: Journal of Language and Culture is concerned with the study of linguistics and literature. Preference is given to articles of English Literatures, Linguistics, and Social Studies. The journal is published twice a year in May and November presenting articles containing analyses, studies, application of theories, research report, material development, teaching and learning languages and reviews. Contributors are invited from both members of and non-members of the English Department of Udayana University.

SUBMISSION: manuscripts for publication must be in English language and sent to the editor one month prior to the first date on the month of the publication. Authors are obliged to register as an author in our OJS site https://ojs.unud.ac.id/index.php/languange and upload the manuscript to this site.

\section{We accept manuscripts with the following classification}

1. An original scientific paper that presents the results of original research that was not previously published in either full or preliminary form.

2. A preliminary communication that contains at least one new scientific fact or result that requires immediate publication, but it should not contain enough details to test the described results, as is the case with original scientific articles.

3. A review article that contains an overall review of recent and current research in a specific area. Papers in this category are surveys in nature that should contain critical references and evaluations. The references must be complete enough to permit a good insight into the subject-matter.

4. A professional paper that does not have to be based on original research, but it should contribute to the application of well-known research results and present theoretical conceptions.

Length: The length of your manuscript should be around $6-10$ pages

Detailed format of the submission, please use the following template https://drive.google.com/file/d/0Bw8hLzLQXo1RZXhKVVF5UUljQXM/view?usp=sharing

\section{ACCEPTANCE CONSIDERATION:}

1. It is important to consider and conclude if the paper makes a valuable contribution to existing knowledge and literature in terms of theory development, new data, new methodology, etc.

2. It is important to match the paper written and submitted according to the Journals Instructions for the authors.

3. It is important to check that the paper written and presented up to publishable standards of the Journal in terms of: whether any concepts have been defined adequately, whether the paper is well structured with coherent argumentation and well integrated, clarity of any statistical data, tables and diagrams, whether the title reflects the contents of the paper accurately, if any part of the paper should be cut out, restructured or further developed.

4. It is important to check appropriateness of referencing in terms of giving adequate credit to other contributors in the field, major omissions and whether the references are complete and written correctly. 